\title{
Novel Treatment for Lead Exposure in Children with Autism
}

\author{
Ahmad Ghanizadeh
}

Received: 27 July 2010 / Accepted: 30 July 2010 /

Published online: 13 August 2010

(C) Springer Science+Business Media, LLC 2010

Lead can inhibit the ionotropic N-methyl-daspartate type of glutamate receptors leads to the gene and protein expression of NMDAR subunits changes [6]. Moreover, the correlation of gene expression and lead levels in blood in children with autism compared to typically developing controls is different [12]. Even very low level of lead exposure in childhood may cause lifelong impairment of attention, memory and learning deficits [1,8].

Meanwhile, urinary lead excretion rate in autism is deceases in compare to typically developing control group [13]. In addition, the level of lead in hair [5, 7] and nail [7] of children with autism is higher than healthy children group [7]. However, the management of this high level of lead is not fully clear. Chelating therapy with succimer (dimercaptosuccinic acid) decreases blood lead levels [11] but it does not improve cognition, behavior, or neuropsychological function [2]. So, the prevention of exposure to lead or some alternative methods is required [2]. Herein, a novel hypothesized clinical and research implication for methionine choline as a novel treatment for lead exposure in children with autism is mentioned.

A natural chelating agent for heavy metals is Methionine [4]. L-methionine is also an antioxidant for lead induced oxidative stress [10]. In addition, prophylactic supplementation of methionine is effective for increasing superoxide dismutase and the prevention of lead neurotoxicity induced learning and memory impairment [3]. Oxidative stress in autism is higher than healthy individuals [9]. In addition, methionine choline reverses lead-induced cognitive deficits [4].

So, considering the high level of lead in autism [5, 7], ineffectiveness of chelating therapy for improving cognition, behavior, or neuropsychological function [2], the need for finding some alternative methods for management of neuropsychological impairments due to lead [2], considering the nutrient methionine for prevention of lead neurotoxicity [3], and improvement of lead-induced cognitive deficits by methionin choline, it is worth conducting studies such as translational clinical trials that may open a new media for treatment of at least some children with autism.

\footnotetext{
A. Ghanizadeh $(\square)$

Research Center for Psychiatry and Behavioral Sciences, Department of Psychiatry,

Shiraz University of Medical Sciences, Hafez Hospital, Shiraz, Iran

e-mail: ghanizad@sina.tums.ac.ir
} 


\section{References}

1. Bellinger DC (2008) Very low lead exposures and children's neurodevelopment. Curr Opin Pediatr 20:172-177

2. Dietrich KN, Ware JH, Salganik M, Radcliffe J, Rogan WJ, Rhoads GG, Fay ME, Davoli CT, Denckla MB, Bornschein RL, Schwarz D, Dockery DW, Adubato S, Jones RL (2004) Effect of chelation therapy on the neuropsychological and behavioral development of lead-exposed children after school entry. Pediatrics 114:19-26

3. Fan G, Feng C, Li Y, Wang C, Yan J, Li W, Feng J, Shi X, Bi Y (2009) Selection of nutrients for prevention or amelioration of lead-induced learning and memory impairment in rats. Ann Occup Hyg 53:341-351

4. Fan G, Feng C, Wu F, Ye W, Lin F, Wang C, Yan J, Zhu G, Xiao Y, Bi Y (2010) Methionine choline reverses lead-induced cognitive and $\mathrm{N}$-methyl-d-aspartate receptor subunit 1 deficits. Toxicology 272:23-31

5. Fido A, Al-Saad S (2005) Toxic trace elements in the hair of children with autism. Autism 9:290-298

6. Guilarte TR, McGlothan JL, Nihei MK (2000) Hippocampal expression of N-methyl-D-aspartate receptor (NMDAR1) subunit splice variant mRNA is altered by developmental exposure to $\mathrm{Pb}(2+)$. Brain Res Mol Brain Res 76:299-305

7. Lakshmi Priya MD, Geetha A (2010) Level of trace elements (Copper, Zinc, Magnesium and Selenium) and toxic elements (Lead and Mercury) in the hair and nail of children with autism. Biol Trace Elem Res (in press)

8. Lanphear BP, Dietrich K, Auinger P, Cox C (2000) Cognitive deficits associated with blood lead concentrations $<10$ microg/dL in US children and adolescents. Public Health Rep 115:521-529

9. McGinnis WR (2004) Oxidative stress in autism. Altern Ther Health Med 10:22-36, quiz 37, 92

10. Patra RC, Swarup D, Dwivedi SK (2001) Antioxidant effects of alpha tocopherol, ascorbic acid and Lmethionine on lead induced oxidative stress to the liver, kidney and brain in rats. Toxicology 162:81-88

11. Rogan WJ, Dietrich KN, Ware JH, Dockery DW, Salganik M, Radcliffe J, Jones RL, Ragan NB, Chisolm JJ Jr, Rhoads GG (2001) The effect of chelation therapy with succimer on neuropsychological development in children exposed to lead. N Engl J Med 344:1421-1426

12. Tian Y, Green PG, Stamova B, Hertz-Picciotto I, Pessah IN, Hansen R, Yang X, Gregg JP, Ashwood P, Jickling G, Van de Water J, Sharp FR (2009) Correlations of gene expression with blood lead levels in children with autism compared to typically developing controls. Neurotox Res (in press)

13. Yorbik O, Kurt I, Hasimi A, Ozturk O (2010) Chromium, cadmium, and lead levels in urine of children with autism and typically developing controls. Biol Trace Elem Res 135:10-15 